\title{
GENETIC DIVERSITY AND STRUCTURE OF Oenocarpus mapora GERMPLASM CONSERVED AT EASTERN AMAZON ${ }^{1}$
}

\author{
ELISA FERREIRA MOURA ${ }^{2}$, MARIA DO SOCORRO PADILHA DE OLIVEIRA ${ }^{3}$, \\ DIEHGO TULOZA DA SILVA ${ }^{4}$, LÍGIA CRISTINE GONÇALVES PONTES ${ }^{5}$
}

\begin{abstract}
The aim of this study was to evaluate the genetic diversity and structure in the germoplasm of Oenocarpus mapora conserved at Eastern Amazon. Thus, 88 individuals were genotyped with five microsatellite loci. These individuals belong to 24 accessions that were sampled in eight sample places of three Brazilian Amazon states conserved at the Active Germplasm Bank (AGB) of Embrapa Eastern Amazon. All loci were polymorphic and they generated 85 alleles with an average of 17 alleles per loci. Total genetic diversity $\left(\mathrm{H}_{\mathrm{E}}\right)$ was 0.48 . Sample places were considered genetically distinct, with $\theta p=0.354$. The analysis of molecular variance (AMOVA) identified that the genetic portion among areas was of $36.14 \%$ and within $63.86 \%$. The Nei distances varied from 0.091 between Abaetetuba and Santo Antônio do Tauá, both in the state of Pará (PA), to 4.18, between Parintins, AM and Rio Branco, AC. By means of Bayesian analysis, it was identified nine clusters that compose the accessions of the germplasm bank, with different distributions among individuals. The study showed high fixation rates per sample area, which indicates that there may have been significant inbreeding or crossing among parental individuals. It suggests that future samples should be made of different plants in natural populations. Even though, it was verified that there is considerable genetic variation in the germplasm of $O$. mapora.
\end{abstract}

Index terms: Arecaceae, molecular markers, microsatellites, plant genetic resources.

\section{DIVERSIDADE E ESTRUTURAÇÃO GENÉTICA EM GERMOPLASMA DE Oenocarpus mapora CONSERVADO NA AMAZÔNIA ORIENTAL}

RESUMO - O estudo teve como objetivo avaliar a diversidade e a estruturação genética em germoplasma de Oenocarpus mapora conservado na Amazônia Oriental. Para isso, foram genotipados com cinco locos microssatélites 88 indivíduos pertencentes a 24 acessos conservados no Banco Ativo de Germoplasma (BAG) da Embrapa Amazônia Oriental e coletados em oito locais distintos de três estados da Amazônia brasileira. Todos os locos foram polimórficos, gerando 85 alelos e média de 17 alelos por loco. A diversidade genética total $\left(\mathrm{H}_{\mathrm{F}}\right)$ foi de 0,48 . As áreas de coleta foram consideradas geneticamente distintas, com $\theta \mathrm{p}=$ 0,354. A análise de variância molecular (AMOVA) identificou que a porção de variação genética entre as áreas foi de $36,14 \%$, e dentro, de $63,86 \%$. As distâncias de Nei variaram de 0,091 , entre as áreas de coleta de Abaetetuba e Santo Antônio do Tauá, no Estado do Pará, a 4,18, entre as áreas de coleta de Parintins, no Amazonas e Rio Branco, no Acre. Estudo por meio de abordagem bayesiana identificou a existência de nove populações que compõem as amostras do BAG analisado, com diferentes distribuições entre as amostras. $\mathrm{O}$ estudo mostrou alta taxa de endogamia por área de coleta, indicando que pode haver significativas taxas de autofecundação ou cruzamento aparentado nessa espécie, sugerindo que as coletas de amostras devam ser feitas de diferentes plantas nas populações naturais. Mesmo assim, foi identificado que há considerável variação genética no germoplasma de $O$. mapora avaliado.

Termos para indexação: Arecaceae, marcador molecular, microssatélites, recursos genéticos vegetais.

\footnotetext{
'(Trabalho 208-14). Recebido em: 18-07-2014. Aceito para publicação em: 13-04-2015.

${ }^{2}$ Biologist, Researcher A of Embrapa Eastern Amazon, Av. Dr. Enéas Pinheiro, s/n - Marco. Zip-code: 66095-903, Belém, PA, Brazil. E-mail: elisa.moura@embrapa.br

${ }^{3}$ Agronomist, Researcher A of Embrapa Eastern Amazon. E-mail: socorro-padilha.oliveira@embrapa.br

${ }^{4}$ Biologist, Master's degree student at Celullar Biology, Federal University of Pará, , Campus Universitário do Guamá, Rua Augusto Corrêa, no.1, Instituto de Ciências Biológicas - Campus Básico, CEP: 66075-110, E-mail: dbiotuloza@hotmail.com

${ }^{5}$ Biological Sciences student, Federal University of Pará, Instituto de Ciências Biológicas - Campus Básico. E-mail: lilikbiologia@ yahoo.com.br
}

Rev. Bras. Frutic., Jaboticabal - SP, v. 37, n. 4, p. 984-992, Dezembro 2015 


\section{INTRODUCTION}

Among the genus of palm species common in the Amazon that have potential for commercial use, the Oenocarpus species have notable characteristics. Five Oenocarpus species occur in the Amazon Forest. The species O. mapora, also known as 'bacabi' or 'bacabinha', is relevant for its use in food, which is obtained from its fruits and palm-of-heart. The fruit pulp produces a beverage that is much appreciated and can be locally consumed or commercially exploited. Its heart-ofpalm also has fine organoleptic characteristics. In addition, oil can be obtained similar to the olive oil from its fruits (BALICK, 1986). This palm species is largely used by local communities where it is abundant (ZAMBRANA et al., 2007), but its market is still local.

Although descriptions mention that $O$. mapora in Brazil occurs only in the West of the Brazilian Amazonia, which includes the state of Acre and the Southwest of the state of Amazonas (BALICK, 1986; LORENZI et al., 2010), samples were collected in the East, precisely on the Northeast of the state of Pará and in the borders of Pará and Amazonas.

The possibility to maintain a part of genetic variability of $O$. mapora on germplasm banks reduces the risks of lost due to environmental degradation. For this to be obtained, the phase of genetic variation analysis is crucial to establish sample strategies and procedures for conservation and management (CIBRIAN-JARAMILLO et al., 2013). From 1984 to 1992, Embrapa Eastern Amazon realized samples of Oenocarpus species in several sites of Amazonia, including samples of O. mapora, to establish a germplasm bank in its facilities. Nowadays, this bank represents the only source of genetic resources of these species in Brazil, and possibly in the world.

The genetic study of samples collected in different sites allows evaluating the level of genetic variation structure and the possibility of genetic erosion (CIBRIAN-JARAMILLO et al., 2013). This information allows the identification of critical sites for sample in order to establish and enrich germplasm banks and help to conduct in situ conservation programs.

Microsatellite markers or SSRs (single sequence repeats) are sequences of one to six base pairs that occur in great abundance in the genome of eukaryotes. In addition to the great abundance, SSR markers are commonly homogeneously distributed in the genome, generate great information per locus and have high reproducibility (KALIA et al., 2011). They also permit to estimate several population genetic parameters due to their multiallelism and codominant heritage. Microsatellite have been used to evaluate the population dynamics of palm species (OTTEWELL et al., 2012), to generate information for palm management (NAMOFF et al., 2011; NAZARENO; REIS, 2014) and in the analysis of genetic variation kept on germplasm banks (OLIVEIRA et al., 2010).

Thus, the aim of this study was to verify the genetic diversity and structure of germplasm of $O$. mapora conserved at a germplasm bank from Eastern Amazon.

\section{MATERIAL AND METHODS}

The Oenocarpus complex Germplasm Bank of Embrapa Eastern Amazon was established based on samplings between 1984 and 1992. Samples were obtained in the Brazilian States of Acre, Amazonas and Pará. The bank is located in Belém, Pará, Brazil, $15 \mathrm{~km}$ from the local Embrapa head office. In each sample area, fruits were sampled from each matrix plant, which represents an accession. Thus, each accession from the germplasm bank represents an open-pollinated family.

To estimate the genetic variability of $O$. mapora maintained in the bank, we selected 88 plants, which belonged to 24 accessions from eight different sample areas (Table 1). Figure 1 shows the sample places. Total genomic DNA was extracted according to a procedure similar to that of Doyle and Doyle (1990). Leaflets were macerated with liquid nitrogen, and polyvinylpyrrolidone (PVP) and $3 \mathrm{~mL}$ CTAB extraction buffer ( $2 \%$ CTAB, $5 \mathrm{M} \mathrm{NaCl}, 0.5$ M EDTA, PVP, $1 \mathrm{M}$ Tris- $\mathrm{HCl}$, and sterile water) were added to the macerate. The macerate was homogenized and incubated in hot water bath at 65 ${ }^{\circ} \mathrm{C}$ for $1 \mathrm{~h}$. Afterwards, chloroform:isoamyl alcohol (24:1) was added followed by homogenization, and the sample were centrifuged for $10 \mathrm{~min}$ at 10,000 rpm. Three milliliters of $95 \%$ ethyl alcohol was added to the supernatant to precipitate the DNA, and the samples were centrifuged for $10 \mathrm{~min}$ at 10,000 rpm. Next, the precipitate was washed with $70 \%$ ethyl alcohol for $10 \mathrm{~min}$ and centrifuged at 5000 $\mathrm{rpm}$. DNA samples were resuspended in $300 \mu \mathrm{L} \mathrm{TE}$ buffer (10 mM Tris-HCl, $1 \mathrm{mM}$ EDTA, $\mathrm{pH}$ 8.0) and RNAse. DNA was quantified on a $1 \%$ agarose gel using lambda phage DNA as a standard, at different concentrations $\left(50,100\right.$ and $\left.200 \mathrm{ng} \mu \mathrm{L}^{-1}\right)$.

For PCR reactions, it was used five microsatellite primers: AG5-5\#12, developed by 
Lepsch-Cunha et al. (2003), and Ob03, Ob07, Ob15 and Ob17, by Montufar et al. (2007). PCR was performed in a final volume of $20 \mu \mathrm{L}$, containing $30 \mathrm{ng}$ genomic DNA, $50 \mu \mathrm{M}$ of each $\mathrm{dNTP}, 0.1 \mu \mathrm{M}$ primer (forward and reverse), 1.0 $\mathrm{mg} \mathrm{mL}^{-1}$ BSA (bovine serum albumin), 0.6 U Taq DNA polymerase (Invitrogen, Brazil) and reaction buffer containing $1 \mathrm{mM} \mathrm{MgCl}_{2}$ supplied by the manufacturer. Reactions were carried out in 0.2 $\mathrm{mL}$ microtubes and amplified on an Amplitherm TX96 thermocycler programmed according to Montufar et al. (2007). Annealing temperatures varied from 56 to $59{ }^{\circ} \mathrm{C}$. Reaction products were run in vertical electrophoresis in $6 \%$ acrylamide gel and stained with silver nitrate. Gels were visually interpreted and each primer represented one locus and each band with a different pattern of migration represented an allele.

The power of discrimination of the primers used was accessed by their combined probability of identity and combined power of discrimination, using their probabilities of identity (PI) and of exclusion (PE), calculated on GenAlEx 6.5 (PEAKALL; SMOUSE, 2012).

It was estimated the parameters of genetic diversity for all individuals and for each sample area: total number of alleles, polymorphic loci, average of alleles, average of effective alleles, observed and expected heterozygosities and fixation index using GenAlEx 6.5. The structuring of the genetic variability was evaluated employing $F, \theta$ p, and $f$ parameters (WEIR; COCKERHAM, 1984), which are analogous to the WRIGHT (1951) $\hat{F}_{\mathrm{IT}}, \mathrm{F}_{\mathrm{ST}}$, and $\mathrm{F}_{\text {IS }}$ statistics, respectively, using the FSTAT 2.9.3.2 software (GOUDET, 2002). Confidence intervals at 95\% probability were obtained for the parameters by bootstrapping 1,000 replicates. The genetic distances among each pair of sample areas based on Nei's (1972) were realized on TFPGA program (MILLER, 1997). The significance of Nei's genetic distances was tested by the permutation of individuals among groups. It was verified the partition of total genetic variation among and within sample areas using AMOVA (EXCOFFIER; SMOUSE; QUATTRO, 1992) using ARLEQUIN 3.5 program (EXCOFFIER; LISCHER, 2010).

The assignment of individuals to populations and relatedness among populations were assessed with Structure 2.2 software (PRITCHARD et al., 2000). The admixture model and the recessive alleles model without prior population information were used. Following a burn-in period of 250,000, six independent runs were carried out for each value of K (from 1 to 10 ) with 250,000 repeats. The true value of $K(\Delta K)$ was chosen according to Evanno et al. (2005).

\section{RESULTS AND DISCUSSION}

The five primers used were polymorphic. They generated a total of 85 alleles, with a mean of 17.00 alleles per locus and ranging from 12 (AG5-5\#12) to 26 alleles (Ob03) (Table 2). These values are comparable to those obtained for Attalea phalerata, a palm common in the South and West of Amazon (CHOO et al., 2010), where the average of alleles was 12.1, with 3 to 25 alleles per locus. For Butia eriospatha, sampled in Brazilian South, the average of alleles was 4.44, with 2 to 9 alleles per locus (NAZARENO; REIS, 2014). The loci AG05 and Ob03 presented the lowest (0.38) and the highest value $(0.62)$, respectively, for expected heterozygosity, with a mean value of 0.48 for the five investigated loci. This value is comparable to that was found for other palm species, such as 0.467 and 0.526 for Astrocaryum aculeatum (RAMOS et al., 2012), 0.49 for Butia eriospatha (NAZARENO; REIS, 2014), but above that was found for other species, such as 0.66 for Oenocarpus bataua (OTTEWELL et al., 2012) and 0.781 for Euterpe edulis (CONTE et al., 2008).

The probability of identity (PI) corresponds to the probability that two individuals share the same multi-loci profile for a certain locus or a group of loci in a population. The probability that two genotypes with the same multiloci profile were identical by chance was of $6.01 \times 10^{-8}$ (Table 2 ) and the power of exclusion considering the five loci was of $99.998 \%$, which indicates the good power of resolution of the primers used.

Estimates of parameters that were related to the genetic structure of the populations were: $F$ $=0.477, \theta \mathrm{p}=0.354$, and $f=0.19$ (Table 3 ). Considering that the confidence intervals did not include zero, the hypothesis that the respective parameters differ from zero was accepted. The differentiation among sample areas was confirmed by AMOVA, where $\mathrm{F}_{\mathrm{ST}}$ $=0.36^{* *}$ (Table 4). The portion of genetic variation among areas was $36.14 \%$ and within, $63.86 \%$. This high differentiation rate among sample areas may be an effect of sampling, since for some sample areas, seeds were sampled from only one individual. The reproductive system of $O$. mapora was considered as allogamous and protandric type (KALUME et al., 2002), and species with this type of reproduction generally contain higher variation within sample areas. However, the high differentiation between the sample places of $O$. mapora may also be related 
to the limited distances covered by beetles, their natural pollinators (COUTURIER et al., 2002; KUCHMEISTER et al., 1998).

The fixation indexes for each sample place varied from -0.29 in Itacoatiara, AM to 0.38 in Abaetetuba, PA (Table 5). The only place that did not show high fixation index was Santo Antônio do Tauá, PA with -0.06, and Itacoatiara, AM showed excess of heterozygotes (Table 5). All other sample places had high fixation indexes. Abaetetuba, PA had one of the greatest representativeness of individuals as source of seeds to compose the germplasm bank (Table 1), but it showed high $f$ value. Studies with other palm species have also verified high levels of fixation indexes, even when bigger samples per population are used, as for Butia eriospatha (NAZARENO; REIS, 2014), Pseudopheonix ekmanii (NAMOFF et al., 2011) and Euterpe edulis (CONTE et al., 2008). However, in a study with a species of the same genus, Oenocarpus bataua, that has similar type of seed dispersion and pollination, and occurs in great agglomerations, a low fixation index was observed in a population highly sampled (OTTEWELL et al., 2012). Thus, the high fixation indexes may be an effect of seed sampling, most of them from a single plant that occurred isolated in the sample area. This may be indicative of inbreeding in the species, in cases where outcrossing was not possible. It also alerts for the need of new sampling based on a higher number of individuals for better representation.

Considering the differentiation based on Nei's (1972) distance, there was significant differentiation among all comparisons (Table 6). The estimative of genetic distance among Santo Antônio do Tauá, PA and Sena Madureira; AC could not be measured, since these populations had no alleles in common. The Nei's genetic distances varied from 0.091, between Abaetetuba and Santo Antônio do Tauá, both in the state of Pará, to 4.18, between Parintins, AM and Rio Branco, AC.

There were 44 private alleles; the majorities (23) for samples from Cruzeiro do Sul, AC (Table 5). This could be an effect of the effective size of alleles for this sample area (4.96 against 10 alleles observed, Table 5). Colares, PA, was the only one that did not have private alleles. It highlights the importance to maintain accessions sampled in different places, since one of the objectives of germplasm banks is to conserve rare genotypes.

The number of genetic groups, $\mathrm{K}$, was calculated as nine by the method proposed by Evanno et al. (2005), based on calculations generated by Structure 2.3.3. ( $K=9$; Figure 2$)$. This number of groups was higher than sample places, which shows different genetic backgrounds in the composition of O. mapora individuals in the germplasm bank. In a previous study, Moura and Oliveira (2012) identified $\mathrm{K}=5$ for the same sample areas when using RAPD markers, confirming the capacity of SSR markers to identify higher polymorphism. According to groups distribution, individuals sampled in Cruzeiro do Sul, AC represent the most heterogeneous material, with different genetic compositions. Part of this genetic composition was apparent in individuals sampled in Abaetetuba, PA, which also shared genetic composition with individuals from Parintins, AM. Individuals from Rio Branco, AC had genetic composition similar to Cruzeiro do Sul and Sena Madureira. It was observed that there was difference among sample places composition when samples were based on only one plant, such as for Itacoatiara, AM (green), Parintins, AM (brown) and Rio Branco, AC (yellow). Sample places where seeds were sampled from a larger number of plants had individuals with mixed genetic compositions (Figure 2). Some samples from Abaetetuba, PA shared the same composition of Cruzeiro do Sul, AC, which may have been an effect of introductions from Acre in the state of Pará. Samples from Colares, PA also had similarity with samples from Parintins, AM. According to Balick (1986) and Lorenzi (2010), the geographic range of $O$. mapora does not include the state of Pará. There are indications that plants of O. mapora occurring in the state of Pará are actually the result of introductions. This hypothesis is congruent with the fact that the seeds that were sampled to compose the germplasm bank were collected on farmers' properties. Some individuals from Colares, PA shared similarity with individuals from Parintins, AM, which may have also been a result of introductions from this region, as observed by Moura and Oliveira (2012) with RAPD markers.

Thus, it was verified that, although samples based on few trees in some sample areas, the genetic diversity maintained in the germplasm bank of O. mapora is high, with great potential for use in the genetic breeding program. The analysis with molecular markers has identified that the genotypes are differentiated by sample areas and that it is worthy to invest in new samples in the places less represented, since places more represented had higher genetic diversity. 
TABLE 1- Number of individuals and accessions of Oenocarpus mapora per sample that composes the germplasm bank of Embrapa Eastern Amazon.

\begin{tabular}{cccc}
\hline Sample place & State & Number of accessions & Number of plants \\
\hline Cruzeiro do Sul & Acre & 10 & 24 \\
Rio Branco & & 1 & 5 \\
Sena Madureira & & 1 & 7 \\
Itacoatiara & Amazonas & 1 & 13 \\
Parintins & & 2 & 8 \\
Abaetetuba & Pará & 7 & 20 \\
Colares & & 1 & 5 \\
Santo Antônio do Tauá & & 1 & 6 \\
\hline Total & & 24 & 88 \\
\hline
\end{tabular}

TABLE 2 - Genetic characteristics of the five microsatellite markers used to analyze the accessions of Oenocarpus mapora sampled in Brazilian Amazonia, showing, for each of them, the Genbank registration number, the allele size range (in $\mathrm{bp}$ ), annealing temperature of the primer pairs $\left(\mathrm{T}_{\mathrm{a}}\right)$, number of alleles per locus (A), probability of identity (PI), power of exclusion (PE), gene diversity $\left(\mathrm{H}_{\mathrm{E}}\right)$ and coefficient of endogamy $(\mathrm{F})$.

\begin{tabular}{lcccccccc}
\hline \multicolumn{1}{c}{ Loci } & GenBank & $\mathrm{T}_{\mathrm{a}}$ & $\begin{array}{c}\text { Allele size } \\
\text { range (bp) }\end{array}$ & Allele number(A) & PI & PE & $\mathrm{H}_{\mathrm{E}}$ & $\hat{\mathrm{F}}$ \\
\hline Ob03 & DQ455754 & $59^{\circ} \mathrm{C}$ & $98-128$ & 26 & $1.3 \times 10^{-2}$ & $95.39 \%$ & 0.62 & 0.22 \\
Ob07 & DQ455758 & $59^{\circ} \mathrm{C}$ & $157-189$ & 14 & $3.1 \times 10^{-2}$ & $89.88 \%$ & 0.48 & -0.02 \\
Ob15 & DQ455766 & $58^{\circ} \mathrm{C}$ & $200-222$ & 17 & $3.9 \times 10^{-2}$ & $87.67 \%$ & 0.44 & 0.16 \\
Ob17 & DQ455768 & $59^{\circ} \mathrm{C}$ & $125-159$ & 16 & $7.4 \times 10^{-2}$ & $79.43 \%$ & 0.48 & 0.01 \\
AG5-5\#12 & AY262721 & $56^{\circ} \mathrm{C}$ & $104-121$ & 12 & $5.1 \times 10^{-2}$ & $84.27 \%$ & 0.38 & 0.44 \\
\hline Total & & & & & $6.0 \times 10^{-8}$ & $99.99 \%$ & & \\
\hline Mean & & & 17.00 & & & 0.48 & 0.15 \\
\hline
\end{tabular}

TABLE 3 - Estimates of genetic parameters for eight sample places of Oenocarpus mapora that composes the germplasm bank of Embrapa Eastern Amazon. Confidence interval at 95\% probability.

\begin{tabular}{lccc}
\hline & $f$ & $\theta \mathrm{p}$ & $\hat{F}$ \\
\hline Estimate & 0.19 & 0.354 & 0.477 \\
Lower limit (CI 95\%) & 0.078 & 0.289 & 0.387 \\
Upper limit (CI 95\%) & 0.295 & 0.412 & 0.575 \\
\hline
\end{tabular}


TABLE 4 - Analysis of molecular variance (AMOVA) for 88 individuals of Oenocarpus mapora sampled in eight sample places in States of Brazilian Amazonia assessed with five microsatellite loci.

\begin{tabular}{ccccc}
\hline Source of variation & DF & SS & VC & $\% \mathrm{TV}$ \\
\hline Among sample places & 7 & 128.59 & 0.81 & 36.14 \\
Within sample places & 168 & 241.92 & 1.44 & 63.86 \\
Total & 175 & 370.51 & 2.25 & \\
\hline Fixation index & $\mathrm{F}$ & $0.36^{* *}$ & &
\end{tabular}

${ }^{a}$ Degrees of freedom (DF), sum of squares (SS), variance components (VC), percentage of total variation (\%TV).** significant at $1 \%$ probability using 1023 permutations.

TABLE 5 - Genetic parameters estimated based on genotyping with five microsatellite loci for each sample area of individuals of Oenocarpus mapora conserved in the germplasm bank of Embrapa Eastern Amazon.

\begin{tabular}{lccccccccc}
\hline \multicolumn{1}{c}{ Sample area } & $\mathrm{N}$ & $\mathrm{P}$ & $\mathrm{N}_{\mathrm{a}}$ & $\mathrm{N}_{\mathrm{e}}$ & $\mathrm{H}_{\mathrm{E}}$ & $\mathrm{H}_{\mathrm{O}}$ & $\mathrm{n}_{\mathrm{P}}$ & $\mathrm{F}_{\mathrm{IS}}$ & $\begin{array}{c}\text { Shannon } \\
\text { index }\end{array}$ \\
\hline Cruzeiro do Sul, AC & 23.8 & $100 \%$ & 10 & 4.96 & 0.74 & 0.65 & 23 & 0.12 & 1.79 \\
Rio Branco, AC & 5.0 & $100 \%$ & 4.2 & 3.02 & 0.66 & 0.44 & 5 & 0.33 & 1.23 \\
Sena Madureira, AC & 7.0 & $60 \%$ & 2.0 & 1.69 & 0.32 & 0.23 & 3 & 0.28 & 0.50 \\
Itacoatiara, AM & 13.0 & $100 \%$ & 2.8 & 2.46 & 0.58 & 0.75 & 1 & -0.29 & 0.93 \\
Parintins, AM & 8.0 & $60 \%$ & 2.2 & 1.57 & 0.29 & 0.22 & 2 & 0.26 & 0.49 \\
Abaetetuba, PA & 20.0 & $100 \%$ & 7.2 & 2.71 & 0.60 & 0.38 & 9 & 0.38 & 1.30 \\
Colares, PA & 5.0 & $80 \%$ & 2.8 & 2.04 & 0.42 & 0.32 & 1 & 0.25 & 0.74 \\
Santo Antônio do Tauá, PA & 6.0 & $80 \%$ & 2.2 & 1.37 & 0.24 & 0.27 & 0 & -0.06 & 0.43 \\
Total & & & & & & & 44 & & \\
\hline
\end{tabular}

$\mathrm{N}$ : average number of individuals, $\mathrm{P}$ : percentage of polymorphic loci, $\mathrm{N}_{\mathrm{a}}$ : Average number of alleles, $\mathrm{N}_{\mathrm{e}}$ : average effective number of alleles, $\mathrm{H}_{\mathrm{E}}$ : expected heterozygosity, $\mathrm{H}_{\mathrm{O}}$ : observed heterozygosity, $\mathrm{n}_{\mathrm{p}}$ : number of private alleles, $\mathrm{F}_{\mathrm{IS}}$ : index of fixation.

TABLE 6 - Pairwise Nei's genetic distances (1972) for sample places of Oenocarpus mapora in three States of Brazilian Amazonia, based on five microsatellite loci.

\begin{tabular}{ccccccccc}
\hline & $\mathrm{CS}$ & $\mathrm{RB}$ & $\mathrm{SM}$ & $\mathrm{IT}$ & $\mathrm{PA}$ & $\mathrm{AB}$ & $\mathrm{CO}$ & $\mathrm{ST}$ \\
\hline $\mathrm{CS}$ & $0.000^{* *}$ & & & & & & & \\
$\mathrm{RB}$ & $1.113^{* *}$ & 0.000 & & & & & & \\
$\mathrm{SM}$ & $1.569^{* *}$ & $0.633^{* *}$ & 0.000 & & & & & \\
$\mathrm{IT}$ & $0.812^{* *}$ & $1.585^{* *}$ & $2.621^{* *}$ & 0.000 & & & & \\
$\mathrm{PA}$ & $3.104^{* *}$ & $4.183^{* *}$ & $3.614^{* *}$ & $1.692^{* *}$ & 0.000 & & & \\
$\mathrm{AB}$ & $2.044^{* *}$ & $1.577^{* *}$ & $3.765^{* *}$ & $1.839 * *$ & $1.000^{* *}$ & 0.000 & & \\
$\mathrm{CO}$ & $2.454^{* *}$ & $3.453^{* *}$ & $4.004^{* *}$ & $2.403 * *$ & $0.651 * *$ & $0.330^{* *}$ & 0.000 & \\
$\mathrm{ST}$ & $3.918^{* *}$ & $1.911^{* *}$ & $\mathrm{nc}$ & $2.228 * *$ & $0.651 * *$ & $0.091 *$ & $0.287 * *$ & 0.000 \\
\hline
\end{tabular}

${ }^{* *}$ Significant at $\mathrm{P}<0.01$ after 1000 permutations, $\mathrm{nc}=$ non calculated.

$\mathrm{CS}=$ Cruzeiro do Sul, AC (Acre); RB = Rio Branco, AC; $\mathrm{SM}=$ Sena Madureira, AC; IT = Itacoatiara, AM (Amazonas); PA = Parintins, $\mathrm{AM} ; \mathrm{AB}=$ Abaetetuba, PA (Pará); $\mathrm{CO}$ = Colares, PA; ST = Santo Antônio do Tauá, PA. 


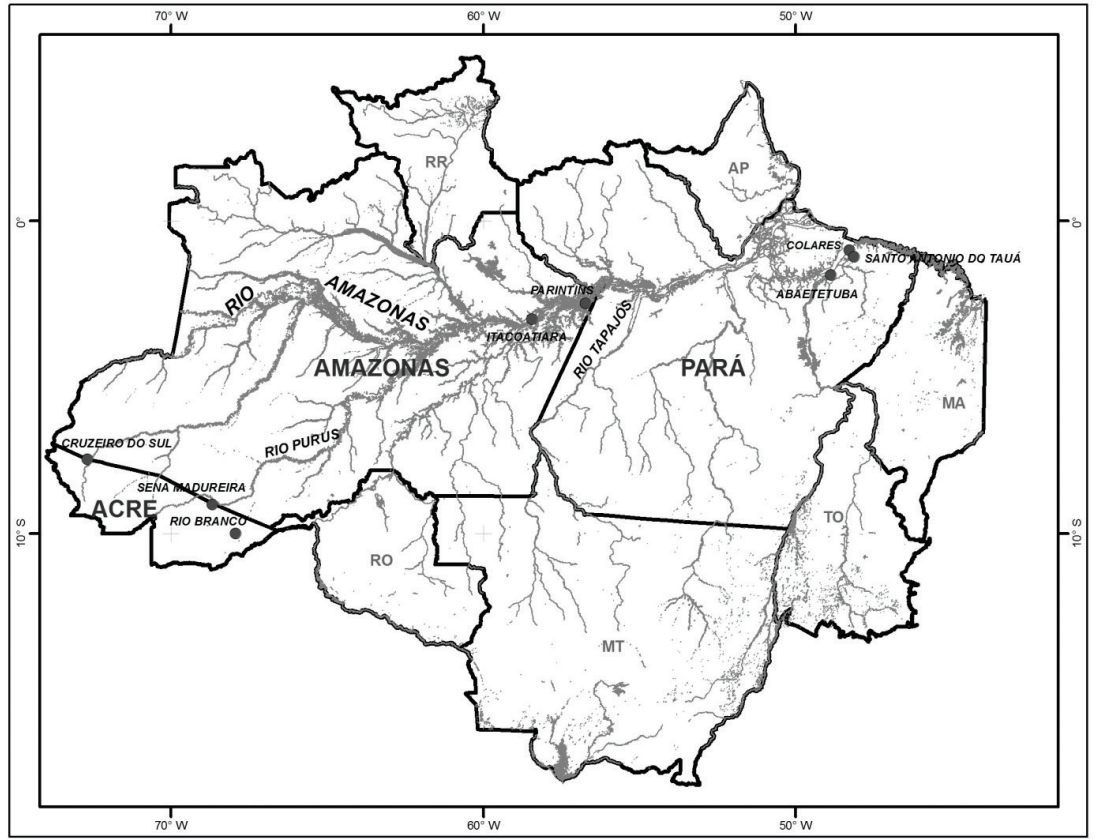

FIGURE 1- Map of the North Region of Brazil. Spots indicate sample places of Oenocarpus mapora accessions analyzed in this study.

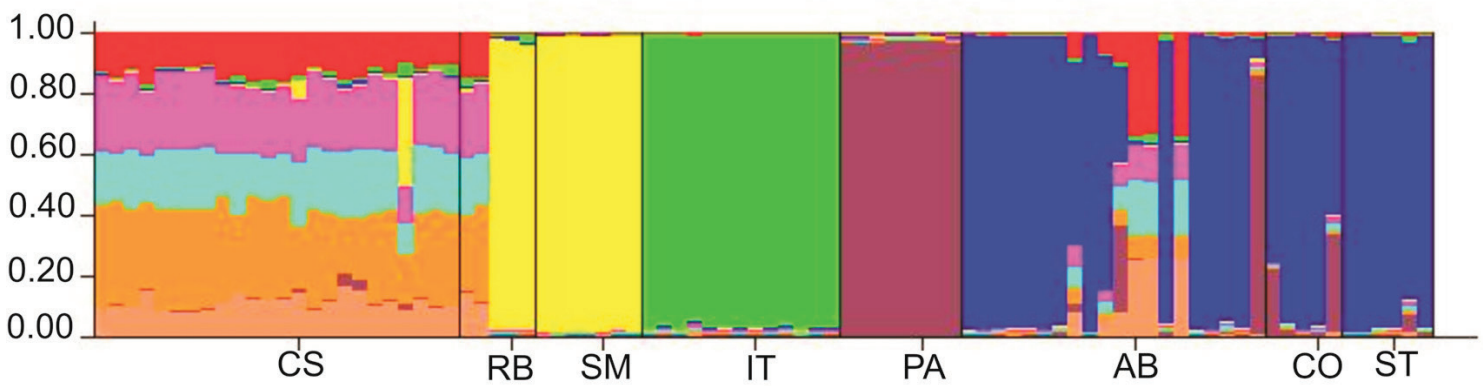

FIGURE 2- Clustering of individuals was done using the Structure software at $\mathrm{K}=9$. Individuals are represented by vertical colored lines. The same color in distinct individuals indicates that they are from the same cluster. Different colors in the same individual indicate the percentage of the genome that is inherited from each cluster. $\mathrm{CS}=$ Cruzeiro do Sul, AC (Acre); RB = Rio Branco, AC; $\mathrm{SM}=$ Sena Madureira, AC; IT = Itacoatiara, AM (Amazonas); PA = Parintins, $\mathrm{AM} ; \mathrm{AB}=$ Abaetetuba, $\mathrm{PA}$ (Pará); $\mathrm{CO}=$ Colares, $\mathrm{PA} ; \mathrm{ST}=$ Santo Antônio do Tauá, PA. 


\section{ACKNOWLEDGMENTS}

Authors thank Amazon Research Foundation (FAPESPA), process 074/2007 and Embrapa (process 01.06.01.007.09.05) for financial support and National Counsel of Technological and Scientific Development (CNPq) for scholarship grants for Moura, E.F. and Pontes, L.C.G.

\section{REFERENCES}

BALICK, M.J. Systematics and economic botany of the Oenocarpus-Jessenia (Palmae) complex. Advances in Economic Botany, Lawrence, v.3, p.1-140, 1986.

CHOO, J.; ISHAK, H.; SIMPSON, B.; MUELLER, U.; JUENGER, T. Characterization of 14 microsatellite loci in a tropical palm, Attalea phalerata (Arecaceae). American Journal of Botany, St. Louis, v.99, n.11, p.105-106, 2010.

CIBRIAN-JARAMILLO, A.; HIRD, A.; OLEAS, N.; MA, H.; MEEROW, A.W.; FRANCISCO-ORTEGA, J.; GRIFFITH, M.P. What is the conservation value of a plant in a botanic garden? Using indicators to improve management of ex situ collections. The Botanical Review, New York v.79, p.559-577, 2013.

CONTE, R.;REIS, M.S.; MANTOVANI, A.; VENCOVSKY, R. Genetic structure and mating system of Euterpe edulis Mart. populations: a comparative analysis using microsatellite and allozyme markers. Journal of Heredity, Edinburg, v.99, p.476-482, 2008.

COUTURIER, G.; OLIVEIRA, M.S.P.; BESERRA, P., PLUOT-SIGWALT, D., KAHN, F. (2002). Biology of Discocoris drakei (Hemiptera: Thaumastocoridae) on Oenocarpus mapora (Palmae). Florida Entomologist, Lutz, v.85, p.261-266, 2002.

DOYLE, J.J.; DOYLE, J.L. Isolation of plant DNA from fresh tissue. Focus, Rockville, v.12, p.13-15, 1990.

EVANNO, G.; REGNAUT, S.; GOUDET, J. Detecting the number of clusters of individuals using the software STRUCTURE: a simulation study. Molecular Ecology, Foster City, v.14, p.2611-2620, 2005 .
EXCOFFIER, L.; LISCHER, H.E. L. Arlequin suite ver 3.5: A new series of programs to perform population genetics analyses under Linux and Windows. Molecular Ecology Resources, Foster City, v.10, p. 564-567, 2010.

EXCOFFIER, N.C.; SMOUSE, P.E.; QUATTRO, J.M. Analysis of molecular variance inferred from metric distances among DNA haplotypes: application to human mitochondrial DNA restriction data. Genetics, Rockville, v.131, p.479-491, 1992.

GOUDET, J. FSTAT: a program to estimate and test gene diversities and fixation indices. Version 2.9.3.2. 2002. Disponível em: < http://www2.unil.ch/popgen/ softwares/fstat.htm>. Acesso em: 10-03-2014.

KALIA, R.K.; RAI, M.K.; KALIA, S.; SINGH, R.; DHAWAN, A.K. Microsatellite markers: an overview of the recent progress in plants. Euphytica, Wageningen, v.177, p.309-334, 2011.

KALUME, M.A.A.; OLIVEIRA, M.S.P.; CARREIRA, L.M.M. Avaliação do sistema reprodutivo em acessos de bacabinha (Oenocarpus mapora Karsten) em Belém-PA. Boletim do Museu Paraense Emilio Goeldi - Botânica, Belém, v.18, p.85-99, 2002.

KUCHMEISTER, H.; WEBBER, A.C.; S ILBERB A UER - GO T T S B ER GER, I.; GOTTSBERGER, G. A polinização e sua relação com a termogênese em espécies de Arecaceae e Annonaceae da Amazônia Central. Acta Amazonica, Manaus, v.28, p. 217-245, 1998.

LEPSCH-CUNHA; N. LUND, C.A.; HAMILTON, M.B. Isolation and characterization of nuclear microsatellite loci in the tropical arboreal palm Oenocarpus bacaba (Arecaceae). Molecular Ecology Notes, Foster City, v.3, p.435-437, 2003.

LEWIS, C.; MOYNIHAN, J.; ABDO, M.; MAUNDER, M.; VON WETTBERG, E.; MEEROW, A.W.; GRIFFITH, M.P.; FRANCISCO-ORTEGA, J. Sweet drinks are made of this: conservation genetics of an endemic palm species from the Dominican Republic. Journal of Heredity, New York, v.102, p.1-10, 2011.

LORENZI, H. Flora brasileira Lorenzi: Arecaceae (palmeiras). São Paulo: Nova Odessa, 2010. 367p. 
MILLER, M.P. TFPGA Version 1.3. A Windows program for the analysis of allozyme and molecular population genetic data. Flagstaff: Department of Biological Sciences Northern Arizona University, 1997.

MONTUFAR, R.; MARIAC, C.; PHAM, L.; PINTAUD, J.C. Isolation of 23 polymorphic micrsatellite loci in the Neotropical palm Oenocarpus bataua Martius (Arecaceae). Molecular Ecology Notes, Foster City, v.7, p.7578, 2007.

MOURA, E.F.; OLIVEIRA, M.S.P. Genetic diversity in a germplasm bank of Oenocarpus mapora (Arecaceae). Genetics and Molecular Research, Ribeirão Preto, v. 11, p. 4008-4018, 2012.

NAMOFF, S.; VELOZ, A.; JIMÉNEZ, F.; RODRÍGUEZ-PEÑA, R.A.; PEGUERO, B.; NAZARENO, A.G.; REIS, M.S. At risk of population decline? An ecological and genetic approach to the threatened palm species Butia eriospatha (Arecaceae) of Southern Brazil. Journal of Heredity, New York, v.105, p.120-129, 2014.

NEI, M.Genetic distance between populations. American Naturalist, Chicago, v.106, p.283-92, 1972.

OLIVEIRA, M. do S. P. de ; SANTOS, J. B. dos ; AMORIM, E. P. ; FERREIRA, D. F. Variabilidade genética entre acessos de açaizeiro utilizando marcadores microssatélites. Ciência e Agrotecnologia, Lavras, v. 34, p. 1253-1260, 2010.
OTTEWELL，K.; GREY, E.; CASTILLO, F.; KARUKIAN, K. The pollen dispersal kernel and mating system of an insect-pollinated tropical palm, Oenocarpus bataua. Heredity, London, v.109, p.332-339, 2012.

PEAKALL, R.; SMOUSE, P.E. GenAlEx 6.5: genetic analysis in Excel. Population genetic software for teaching and research-an update. Bioinformatics, Oxford, v.28, p. 2537-2539, 2012.

PRITCHARD, N.K.; STEPHENS, M.; DONNELLY, P. Inference of population structure using multilocus genotype data. Genetics, Rockville, v.155, p.945959, 2000.

RAMOS, S.L.F.; MACEDO, J.L.V.; LOPES, M.T.G.; BATISTA, J.S.; FORMIGA, K.M.; SILVA, P.P.; SAULO-MACHADO, A.C.; VEASEY, E.A. Microsatellite loci for tucumã of Amazonas (Astrocaryum aculeatum) and amplification in other Arecaceae. American Journal of Botany, St. Louis, e508-e510, 2012.

WEIR, B.S.; COCKERHAM, C.C. Estimating F-Statistics for the analysis of population structure. Evolution, Lawrence, v.38, n.6, p.1358-1370, 1984.

WRIGHT, S. The genetical structure of populations. Annals of Eugenics, London, v.15, p.323-353, 1951.

ZAMBRANA, N.Y.; BYG, A.; SVENNING, J.C.; MORAES, M.; GRANDEZ,C.; BALSLEV H. Diversity of palm uses in the western Amazon. Biodiversity Conservation, London, v.16, p. 27712787, 2007. 